A N N A L E S

UNIVERSITATIS MARIAE CURIE-SKŁODOW S A

LUBLIN - POLONIA

VOL. LXXIV

SECTIO B

2019

JOANNA SIEKIERA

ORCID ID 0000-0003-0125-9121

Wydział Prawa, Bergen Pacific Studies Research Group

Uniwersytet w Bergen

joanna.siekiera@uib.no

\title{
Prawna sytuacja ludności Rapa Nui w świetle regionalnych norm prawa międzynarodowego
}

Legal situation of Rapa Nui in the light of the regional norms of international law

\begin{abstract}
The aim of the article was to present, as well as to analyse legally, the situation of the population of Rapa Nui (Easter Island) in the light of regional norms of international law. Rapa Nui was annexed by Chile in 1888. Since then violations of the rights of indigenous peoples living on the Island have been observed. The legal situation of the inhabitants of Easter Island is difficult due to the Chilean government's failure to respect, i.a., the right to self-determination or the right to environmental protection. The research assumption is, therefore, to discuss the actual situation in which indigenous peoples find themselves and then to confront it with the legal situation, which does give the opportunity to improve the difficult position of Rapa Nui. There are a number of American regional norms, along with a series of judgements of the Inter-American Court of Human Rights, which might help local people in regaining their freedoms, as well as in improving their material well-being. The research method used was the method of legal analysis, consisting of analysing the content of binding legal regulations, internal law arrangements, regional judiciary, and international agreements regulating the situation of indigenous minorities, as well as internal official data. The results show solid legal possibilities for the Rapa Nui population, which has the basis to enforce its rights in the field of universal civil rights, respect for their constitutional social and economic rights, along with the right to live in the clean natural environments.
\end{abstract}

Keywords: Rapa Nui, Easter Island, Chile, international law

Abstrakt: Celem artykułu było zaprezentowanie sytuacji ludności Rapa Nui (Wyspy Wielkanocnej)
oraz dokonanie jej prawnej analizy w świetle regionalnych norm prawa międzynarodowego. Rapa
Nui została zaanektowana przez Chile w 1888 r. Od tego czasu obserwuje się łamanie praw lud-
ności autochtonicznej zamieszkującej Wyspę. Sytuacja prawna mieszkańców Wyspy Wielkanocnej
jest trudna ze względu na nierespektowanie przez chilijski rząd m.in. prawa do samostanowienia
czy prawa do ochrony środowiska naturalnego. Założeniem badawczym było omówienie sytuacji
faktycznej, w jakiej znajdują się autochtoni, oraz skonfrontowanie jej z sytuacją prawną, która 
daje sposobność do polepszenia trudnej pozycji Rapa Nui. Istnieje szereg norm prawa regionalnego Ameryki, wraz z serią wyroków Międzyamerykańskiego Trybunału Praw Człowieka, które mogą pomóc w faktycznym odzyskaniu swobód przez miejscową ludność, a także doprowadzić do poprawy ich sytuacji materialnej. Zastosowana metoda badawcza to metoda analizy prawnej, polegająca na analizie treści obowiązujących regulacji prawnych, umów prawa wewnętrznego, regionalnego sądownictwa oraz międzynarodowych porozumień regulujących sytuację mniejszości autochtonicznych, a także wewnętrznych danych urzędowych. Wyniki wskazują na konkretne możliwości prawne dla ludności Rapa Nui, która ma podstawy egzekwować swoje prawa w zakresie uniwersalnych swobód obywatelskich, respektowania ich konstytucyjnych praw społecznych i ekonomicznych wraz z prawem do życia w czystym środowisku naturalnym.

Słowa kluczowe: Rapa Nui, Wyspa Wielkanocna, Chile, prawo międzynarodowe

\section{WPROWADZENIE}

Od 1888 r., kiedy to władze Chile zaanektowały wyspę Rapa Nui na Pacyfiku Południowym, nazywając ją Wyspą Wielkanocną (hiszp. Isla de Pascua), obserwuje się łamanie praw ludności autochtonicznej. Pomimo nadania prawnych ram przekazania zwierzchnictwa terytorialnego przez starostów plemiennych na rzecz rządu w Santiago, co dokonało się poprzez pełne wad formalnych ${ }^{1}$ porozumienie bilateralne, trudno jednoznacznie określić sytuację prawną mieszkańców. Autochtoni pochodzenia polinezyjskiego nazywają siebie Rapa Nui, mówią własnym językiem, posiadają katalog wartości (w tym wierzeń) odmiennych od tych prezentowanych przez kontynentalnych kolonizatorów. Fundamentalne zarzuty, jakie należy postawić w przypadku narodu Rapa Nui, to nierespektowanie przez Republikę Chile prawa do samostanowienia, prawa do ochrony środowiska naturalnego wraz z jego naturalnymi zasobami oraz prawa do ziemi i poszanowania miejsc kultu religijnego. Są to główne założenia, jakie zostaną zaprezentowane oraz przeanalizowane od strony prawnomiędzynarodowej. Wobec uchybień względem pierwotnych założeń prawa międzynarodowego odnoszącego się do ludności Wyspy, a nawet ich celowego łamania przez stronę chilijską, należy wskazać szereg norm o zasięgu uniwersalnym, a także regionalnym

\footnotetext{
1 Mowa o Akcie Woli (hiszp. Acuerdo de Voluntades) z dnia 9 września 1888 r. Strona Rapa Nui została wprowadzona w błąd, mimo że domagała się dokonania wyraźnego wpisu w treści dokumentu o suwerenności Wyspy oraz wyłącznym zarządzie terenem przez plemiona ludności autochtonicznej. Chilijczycy nie wywiązali się jednak z tego warunku. Określili siebie jako „przyjaciół Wyspy” i nie wspomnieli o cesji ziemi oraz innych praw majątkowych. Ponadto nie ratyfikowali Aktu w swoim wewnętrznym prawodawstwie, co de iure oznacza, iż porozumienie nie było nigdy wiążące, a de facto - strona chilijska nie działała w dobrej wierze i bezprawnie zajęła Wyspę.
} 
(panamerykańskim), które mogą posłużyć do usankcjonowania prawa Rapa Nui do życia w spokoju i dobrobycie.

Należy podkreślić, iż tezą niniejszego artykułu nie jest bezwzględny apel czy prawny postulat uzyskania niepodległości przez Rapa Nui ani związane z tym uznanie prawnomiędzynarodowe nowej suwerennej jednostki na arenie międzynarodowej ${ }^{2}$. Konieczne jest bowiem dostrzeżenie wachlarza problemów, z jakimi borykają się mieszkańcy Wyspy, a na które można znaleźć inne rozwiązania przewidziane prawem międzynarodowym. Tematyka wciąż jest mało znana w literaturze europejskiej, stąd motywem podjęcia badań stała się chęć jej przybliżenia polskiemu czytelnikowi. Choć napięte relacje na linii Chile - Rapa Nui są powszechnie znane, to wartością dodaną niniejszego opracowania może być wskazanie konkretnych umocowań prawnych na rzecz praw ludności Wyspy Wielkanocnej.

\section{MATERIAŁ I METODY}

Proces badawczy opierał się o badania niereaktywne. Badania te uwzględniają metodę analizy treści literatury przedmiotu (w głównej mierze anglojęzycznej, lecz także polskiej) oraz regulacji prawnych (prawa międzynarodowego, regionalnego i wewnętrznego w oryginalnych wersjach - angielskiej i hiszpańskiej). Następnie zastosowano metodę analizy danych urzędowych (w tym organów organizacji międzynarodowych), która umożliwia analizę istniejących dokumentów strategiczno-programowych. Za źródła danych wtórnych posłużyły m.in. kompendia statystyczne pozarządowych organizacji międzynarodowych oraz przygotowane przez organizacje regionalne analizy poziomu rozwoju i praworządności. Wreszcie konieczne było prześledzenie dziedzictwa prawnego ONZ i wybranych selektywnie traktatów ustanawiających organizacje regionalne. Ten fragment pracy ma wymiar komparatystyczny.

\section{WYNIKI}

Źródłem większości, by nie powiedzieć wszystkich, problematycznych kwestii rozwojowo-cywilizacyjnych ludności Rapa Nui jest ustrojowe zablokowanie możliwości samostanowienia ze strony rządu w Santiago. Chile, zgodnie

\footnotetext{
2 Takie artykuły zazwyczaj mają wymiar polityczny, często są po prostu stronnicze. Zamiarem autorki jest natomiast ocena prawna sensu stricto.
} 
ze swoją ustawą zasadniczą ${ }^{3}$, jest unitarną demokratyczną republiką, a o odrębności czy specjalnym statucie Wyspy Wielkanocnej nie ma mowy. Co istotne, nigdy władze chilijskie nie nazwały zajętego terenu kolonią ${ }^{4}$, co nałożyłoby na nie wymóg specjalnego traktowania Rapa Nui oraz szereg praw i obowiązków prawnomiędzynarodowych zgodnie z doktryną Organizacji Narodów Zjednoczonych $^{5}$. Chile prowadzi aktywną politykę, której celem jest wynarodowienie mieszkańców Wyspy oraz wykorzystanie jej dóbr naturalnych (wraz z dziedzictwem niematerialnym) na własne potrzeby. Mowa tu o dwóch fundamentalnych pogwałceniach praw ludności tubylczej poprzez stałą migrację z kontynentu, trwale zmieniającą strukturę etniczną Rapa Nui, oraz eksploatowanie Wyspy na potrzeby zwiększenia przychodów z turystyki.

Odnośnie do pierwszego zagadnienia chilijskiego zasiedlania Wyspy Wielkanocnej należy posłużyć się danymi liczbowymi. Zgodnie z ostatnim spisem powszechnym przeprowadzonym w 2017 r. na Wyspie mieszka 7750 osób (Romero 2012). Wartość ta podwoiła się jedynie w ciągu ostatniej dekady (https://www.france24.com/en/20180730-easter-island-rapa-nui-chile-restrictlength-stay-non-tourists). Miejscowe klany, w liczbie 36, stanowią ok. 60\% populacji Wyspy, jednak ta liczba co roku maleje w związku z migracją zarobkową z kontynentalnego Chile. Warto dodać, że dopiero w latach 60. XX w. ludności Rapa Nui pozwolono opuścić największe skupisko, jedyne miasto nieoficjalnie uznawane za stolicę - Hanga Roa, aby osiedlić się poza jego granicami administracyjnymi (Hito 2004; Coulter 2015). Warto przybliżyć proces, który odbył się przed Naczelnym Sądem Chile w 2009 r. po akcji protestacyjnej przeciwko chilijskiej migracji ${ }^{6}$. Wprowadzony po blokadzie przez wyspiarską ludność dokument identyfikacyjny dla każdej osoby przylatującej na Wyspę został uznany za niezgodny z prawem chilijskim, jako że Wyspa stanowi terytorium Chile, a jego obywatele nie mają obowiązku legitymizowania się. Nie zniechęciło to aktywistów z Rapa Nui, którzy udowodnili w wyniku referendum (aż 96\% „za”), że są zgodni co do stanowczego ograniczenia migracji z kontynentalnego Chile (http://www.coha.org/limiting-migration-to-rapa-nui). Jak można było

3 Konstytucja Polityczna Republiki Chile (Constitución Política de la República de Chile de 1980) z dnia 8 sierpnia 1980 r. (Ministerio Secretaría General De La Presidencia CPR Art. $1^{\circ}$ D.O. 24.10.1980 LEY N 19.611 Art. Único No1 D.O. 16.06.1999).

4 Oznacza to, że teren Rapa Nui znajduje się pod bezpośrednim zwierzchnictwem rządu w Santiago, nie posiadając prawnie przewidzianego samorządu terytorialnego czy innej formy autonomii lokalnej.

5 Będzie o tym mowa w dalszej części artykułu.

6 Szerzej na temat kampanii ograniczającej chilijskie osadnictwo zob. https://nvdatabase. swarthmore.edu/content/rapa-nui-campaign-immigration-regulation-2009. 
domniemywać, głos wyspiarskiej ludności oraz ich demokratyczny przejaw woli nie zostały wzięte pod uwagę przez rząd w Santiago.

Celowe zasiedlanie oraz zmiany struktury etnicznej wiążą się nierozerwalnie z degradującym środowisko wyspiarskie corocznym zwiększeniem liczby turystów. Zgodnie z analizą Francesco di Castri z UNESCO w 2003 r. maksymalna wyporność Wyspy to 20 tys. gości (di Castri 2003). Niestety, już w ostatniej dekadzie XX w. liczba ta została przekroczona dwukrotnie, podczas gdy rok 2013 dał gigantyczny przyrost turystów - do 92 tys. (Young 2016). Taka eksploatacyjna polityka turystyczna grozi katastrofą ekologiczną, która wiązać się będzie z zanieczyszczeniem wód gruntowych, stałą degradacją ziemi związaną z długotrwałą erozją gleby, zniszczeniem zasobów morskich, a także częstymi awariami energii (Campbell 2006). Jaka była odpowiedź chilijskich władz na tak daleko idące szkody zarządzanego przez siebie terytorium? Otóż z jednej strony w dniu 25 lipca 2018 r. wprowadzono restrykcje ograniczające pobyt turystów z 90 do 30 dni, z drugiej zaś rząd dąży do wytworzenia „marki” narodowej (chilijskiej) na Rapa Nui, aby przyciągnąć zagranicznych inwestorów. Do takich planów, już znajdujących się w fazie realizacji, należy zaliczyć umowę opiewającą na sumę $160 \mathrm{mln}$ USD celem rozbudowy infrastruktury m.in. lotniska i doków oraz zarządzania odpadami w latach 2015-2020, a także wybudowanie czterohektarowego ${ }^{7}$ centrum handlowego przez niemieckiego inwestora (Young 2016). W 2010 r. wyspiarska ludność próbowała zatrzymać budowę luksusowego hotelu, co spotkało się z brutalnym stłumieniem przez wysłane z kontynentalnej części Chile siły porządkowe (Pawlicki 2014). Sytuacja powtórzyła się w 2015 r. Wówczas aktywiści podjęli próbę zablokowania wjazdu do parku narodowego. Chilijska policja i tym razem rozpędziła tłum. Na przewodników i operatorów wycieczek mianowano od tamtej pory wyłącznie pracowników z kontynentalnej części państwa (Young 2016). To bolesne doświadczenie dało jasny sygnał ludności Rapa Nui, że decyzje co do ich Wyspy podejmuje wyłącznie Chile, a dochody z turystyki będą spływać do chilijskiego budżetu, omijając wyspiarskie potrzeby rynku pracy i opieki społecznej. Dochody z turystyki na Rapa Nui sięgają aż 80\% budżetu narodowego (Jędrusik 2005; Legrand 2013).

Druga wyżej wymieniona inwestycja jest bardzo kontrowersyjna z uwagi na bliskie sąsiedztwo sakralnych budowli Moai, a nawet konieczność ich przeniesienia z pierwotnego miejsca. Stanowi to zatem jawne i bezpodstawne pogwałcenie gwarancji ludności tubylczej do wyrażania swoich przekonań religijnych oraz prawa do użytkowania ziemi zgodnie z ich tradycyjnym przeznaczeniem. Brakuje tu też wymaganej prawem międzynarodowym gwarancji ochrony przed

\footnotetext{
7 Podczas gdy terytorium Wyspy obejmuje zaledwie $163 \mathrm{~km}^{2}$.
} 
jakąkolwiek ingerencją ze strony państwa w te prawa ${ }^{8}$. Aż $71,5 \%$ terytorium Wyspy jest bowiem własnością rządu, a dzielone jest przez Fundusz Vaitea i zarząd parku narodowego - wyłącznych nadzorców zasobów naturalnych. Model zarządzania zakłada brak konsultacji z organizacjami społecznymi Rapa Nui, które na próżno dążą do zalegalizowania swej działalności przez administrację chilijską. Jako jednostki niefunkcjonujące zgodnie z prawem Chile nie są więc brane pod uwagę w dyskusji dotyczącej gospodarowania Wyspą (https://minorityrights.org/minorities/rapanui).

Zanim regionalne rozwiązania prawnomiędzynarodowe zostaną wskazane w kwestii narodu Rapa Nui, konieczne jest prześledzenie prawa wewnętrznego Chile. Już od momentu aneksji Wyspy na lokalnej ludności dopuszczano się nadużyć, czego najokrutniejszym przejawem było uczynienie jej niewolnikami. Co więcej, ostatni król został otruty, a przedstawicieli opozycji antykolonialnej deportowano lub zabito (Pereyra-Uhrle 2011). W 1917 r. wprowadzono zwierzchnictwo nad Wyspą, włączając ją do morskiego terytorium regionu Valparaíso ${ }^{9}$, co wiązało się z egzekwowaniem prawa morskiego ${ }^{10}$. Oznaczało to jednak brak zmiany statusu tubylczej ludności oraz potwierdzenie przynależności ziemi i dóbr do Chile. Nieuznanie odrębności narodowej Rapa Nui zostało skodyfikowane, odstąpiono również od pomysłu nadania osobnego obywatelstwa. Taki stan prawny potwierdziła deklaratywna decyzja władz Valparaíso, według której Wyspa - zgodnie z rzymską doktryną res nullius - podlega prawomocnemu włączeniu pod zwierzchnictwo chilijskie. Postanowienia dokonano, nie przeprowadzając konsultacji z autochtonami (Pereyra-Uhrle 2011). Ogromnie kontrowersyjną zmianą prawną w 1935 r. było objęcie całego terenu Wyspy obszarem parku narodowego. $Z$ jednej strony celem była prawna ochrona (także

\footnotetext{
8 Mówi o tym m.in. art. 26 Deklaracji praw ludów tubylczych z dnia 13 września 2007 r.

9 Rapa Nui pozostaje pod zwierzchnictwem administracyjnym Valparaíso także współcześnie. Pomimo reformy ustrojowej, przeprowadzonej w 2007 r. na podstawie tzw. ustawy 20.193, usankcjonowano stworzenie dwóch terytoriów specjalnych: Wyspy Wielkanocnej oraz Archipelagu Juana Fernandeza. Jednakże pomimo nadania bardziej autonomicznej nazwy samodzielność Rapa Nui jest wciąż odrzucana przez rząd chilijski, co potwierdza ust. 2 ustawy: ,[...] terytoria [...] będą podlegać wspólnym zasadom dotyczącym podziału polityczno-administracyjnego oraz rządu i administracji wewnętrznej państwa” (zob. Reforma konstytucyjna ustanawiająca specjalne terytoria Wyspy Wielkanocnej i archipelagu Juana Fernandeza [Reforma Constitucional Que Establece Los Territorios Especiales De Isla De Pascua Y Archipielago Juan Fernandez] z dnia 30 lipca 2007 r.).

10 Nie można mylić tej dziedziny prawa wewnętrznego z prawem morza, będącym działem prawa międzynarodowego publicznego, określającym m.in. status prawny obszarów morskich oraz statków morskich. Prawo morskie jest dziedziną, dzięki której państwo reguluje swoje stosunki prawne związane z korzystaniem z morza, przede wszystkim poprzez żeglugę morską.
} 
na poziomie międzynarodowym, poprzez włączenie terytorium do światowego dziedzictwa kulturowego UNESCO ${ }^{11}$ ) zasobów naturalnych i archeologicznych, $\mathrm{z}$ drugiej natomiast de iure skutecznie uniemożliwiono jakąkolwiek prawną restytucję ziemi oraz innych dóbr przez tubylczą ludność. W 2003 r. Komisja Prawdy (hiszp. Comisión Nacional de Verdad) lobbująca za prawami mieszkańców Rapa Nui zarekomendowała zwrot bezprawnie zagrabionych terenów wraz z rekompensatą pieniężną (Young 2016). Jej działalność nie miała jednak kompetencji normodawczych. Jako że instrukcje nie posiadały wiążącego efektu, nie zostały wzięte pod uwagę przez władze Chile.

Pewną otwartość władz na konieczność poszanowania prawnej sytuacji Rapa Nui przyniósł czas junty wojskowej rozpoczętej w 1973 r. (pod dyktaturą Augusto Pinocheta, pełniącego do 1990 r. urząd prezydenta). Otóż po raz pierwszy w historii Sergio Rapu Haoa - osoba pochodząca z tubylczej ludności - został wybrany na przedstawiciela lokalnego rządu (zob. https://www.berkeley. edu/news/media/releases/2002/11/peace/rapu.html). Lata 80. XX w. zwiększyły wzrost oczekiwań i jawnych żądań względem rządu w Santiago, dotyczących uznania rekompensat za lata okupacji, niewolnictwa, a także bogacenia się kosztem degradacji środowiska i pogorszenia warunków życia wyspiarskiej ludności.

$\mathrm{Na}$ fali tych społecznych zmian, wraz z zakończeniem wojskowych rządów oraz powolnym przywracaniem instytucji demokratycznego państwa prawa, przegłosowano tzw. Prawo Ludności Autochtonicznej, zwane też ustawą $19.253^{12}$. Szumnie brzmiąca nazwa reformy nie usankcjonowała jednak konstytucyjnego, a zatem zasadniczego uznania ludności tubylczej za osobną grupę społeczeństwa chilijskiego, która charakteryzowałaby się odrębnością przywilejów i specjalną ochroną prawną. Pomimo zapisu w art. 1 jakoby obowiązkiem rządu i narodu Chile było poszanowanie, ochrona oraz promocja praw autochtonów wraz z ich dziedzictwem kulturowym i tradycyjnymi ziemiami, procedura odwoławcza uwzględniała obowiązkową rewizję komisji rządowej, która na każdym etapie mogła odrzucić wniosek. Dodatkową przeszkodą był ograniczony katalog wnioskodawców, jako że zgodnie z definicją ustawową za osobę pochodzenia tubylczego nie uznano wszystkich przedstawicieli plemion indiańskich ${ }^{13}$ zamieszkujących Chile (art. 2). Wprowadzona na mocy ustawy

11 Obecnie 40\% obszaru Wyspy jest wykorzystane jako Park Narodowy Rapa Nui (zob. https://whc.unesco.org/en/list/715).

12 Prawo rozwoju lokalnego (Ley de Desarrollo Indígena) z dnia 5 października 1993 r. (LEY 20117 Art. Único D.O. 08.09.2006).

13 Oprócz Rapa Nui na społeczeństwo Chile składa się aż 10,8\% ludności pochodzenia tubylczego. Grupy etniczne zostały wymienione na stronie Central Intelligence Agency: Mapuche -9,1\%, Aymara - 0,7\%, inni - 1\% (Rapa Nui, Likan Antai, Quechua, Colla, Diaguita, Kawesqar, 
(art. 38) Komisja (hiszp. Corporación Nacional de Desarrollo Indígena) miała za zadanie nadzorować powstanie spisu majątku ludności tubylczej podczas ewentualnych sporów o odszkodowanie. Także tutaj zapisy prawa stanowionego nie brały pod uwagę norm zwyczajowych, a zatem tradycyjnej kultury prawnej (w tym wierzeń) Rapa Nui. Ustawodawca postawił tu jakże trudny do wyegzekwowania warunek formalny - prawo zwyczajowe może posłużyć Komisji, jednakże tylko wówczas, gdy jest ono zgodne z prawem konstytucyjnym Chile (art. 35). Takiej harmonizacji jednak nigdy nie było.

Ustawa 19.253 powstała niejako w odpowiedzi na umowę Międzynarodowej Organizacji Pracy z 1989 r. ${ }^{14}$ dotyczącą ludności tubylczej i plemiennej, która po podpisaniu nie została ratyfikowana w porządku krajowym Chile. $Z$ tego powodu liderzy grup plemiennych (w tym z Rapa Nui) zaproponowali nowelizację aktu. Postulowali uwzględnienie ich prawa do reprezentacji w parlamencie w Santiago, a także zażądali większej autonomii, przejawiającej się w lokalnych samorządach (Gacitúa-Marió 2000; Levine 2016). Postulaty nie spotkały się z przyjęciem ze strony chilijskiej.

\section{DYSKUSJA}

Oceniając ustrojową sytuację Rapa Nui wewnątrz porządku prawnego Chile, należy podkreślić trzy kwestie. Po pierwsze, plemienna jurysdykcja wraz z prawem zwyczajowym i tradycjami Rapa Nui nie jest szanowana w chilijskiej przestrzeni publicznej (w tym prawnej). Po drugie, propozycje państwowych rekompensat zawierają wiele wad formalnych, a także zasadniczą wadę materialną - w tradycji ludności Rapa Nui nie funkcjonuje pojęcie własności prywatnej, gdyż wartością są dobra wspólne (idea „wspólnoty” - wyłącznego posiadacza ziemi). Po trzecie, leżąca odłogiem ziemia, będąca terenem parku narodowego, a wcześniej miejscem, którego tubylcza ludność nie miała prawa użytkować, przestała być żyzna i już nie nadaje się do użytkowania rolniczego. Władze w Santiago muszą zdawać sobie z tego sprawę, a mimo to oferują oddanie ziemi autochtonom jako wyraz refundacji w ramach naprawy szkód (Pereyra-Uhrle 2011).

Jak zatem sytuacja prawna Rapa Nui może być zmieniona zgodnie z postanowieniami prawa międzynarodowego, w tym regulacjami regionalnymi Ameryki

\footnotetext{
Yagan lub Yamana) (https://www.cia.gov/library/publications/resources/the-world-factbook/geos/ print_ci.html).

14 Konwencja MOP nr 169 w sprawie ludności rdzennej i plemiennej z dnia 27 czerwca $1989 \mathrm{r}$.
} 
Łacińskiej? Prawo do samostanowienia przewidziane Kartą Narodów Zjednoczonych z dnia 26 czerwca 1945 r. (Dz.U. 1947, nr 23, poz. 90, Rozdział XI „Deklaracja w Sprawie Obszarów nierządzących się Samodzielnie” oraz Rozdział XII „Międzynarodowy System Powiernictwa”) przewiduje kilka sposobów złożenia swobodnej deklaracji swojej odrębności na arenie międzynarodowej. Tereny kolonialne (nawet pomimo deklaratywnego aktu, jak było w przypadku Wyspy Wielkanocnej) mają niczym nieograniczone prawo do swobodnego wyboru formy egzystencji ustrojowo-politycznej. Niezależnie od tego, czy jednostka terytorialna zdecyduje się na ogłoszenie swojej pełnej suwerenności czy też formy zależności politycznej, musi mieć prawo do kontroli swojego terytorium wraz z jego zasobami. Te wskazania doprecyzowały kolejne posiedzenia Zgromadzenia Ogólnego ONZ poprzez trzy fundamentalne dla procesu dekolonizacji rezolucje z 1960 r. ${ }^{15}$ i 1970 r. ${ }^{16}$ Najistotniejszy zapis dotyczy trzech różnych możliwości legalnego osiągnięcia autonomii dla jednostki, która ,jest geograficznie odseparowana oraz etniczne i/lub kulturowo różnorodna od kraju nią zarządzającego". Pierwsza możliwość to pełna suwerenność na arenie międzynarodowej, druga - wolne stowarzyszenia (free association) z niepodległym państwem, a trzecia - integracja na zasadzie dobrowolności i poszanowania równości z drugim państwem (Hannum 1993).

Niejako na potwierdzenie tych zapisów uchwalono w 1966 r. dwa akty prawne: Międzynarodowy Pakt Praw Obywatelskich i Politycznych z dnia 16 grudnia 1966 r. (Dz.U. 1977, nr 38, poz. 167) oraz Międzynarodowy Pakt Praw Gospodarczych, Społecznych i Kulturalnych z dnia 16 grudnia 1966 r. (Dz.U. 1977, nr 38, poz. 169). Takie powielenie norm w większej liczbie umów międzynarodowych należy tłumaczyć szczególną troską o przestrzeganie praw narodów (w tym ludności postkolonialnej i tubylczej) oraz rozwój dobrobytu niezależnie od formy rządów. W jednobrzmiących art. 1 obu Paktów wpisano normę jakoby „Każdy człowiek ma prawo do samostanowienia”. Można odczytywać to jako dodanie tego uprawnienia do katalogu podstawowych praw każdej istoty ludzkiej, zaraz obok prawa do życia czy godności. Ostatecznie społeczność międzynarodowa nałożyła obowiązki także na państwa. Wprowadzono je celem

15 Deklaracja Zgromadzenia Ogólnego ONZ z dnia 14 grudnia 1960 r. w sprawie przyznania niepodległości krajom kolonialnym GA Res. 1514 (XV); Principles which should guide Members in determining whether or not an obligation exists to transmit the information called for under Article 73e of the Charter, 15 December 1960 GA Res. 1541 (XV).

16 Deklaracja Zgromadzenia Ogólnego ONZ z dnia 24 października 1970 r. w sprawie zasad prawa międzynarodowego dotyczących przyjaznych stosunków i współpracy między państwami GA Res. 2625 (XXV). 
przeciwdziałania cierpieniu narodów niesuwerennych ${ }^{17}$. Brak systemu sankcji oraz kontroli może jednak nieskutecznie skłonić państwa (wszak byłych kolonizatorów) do przestrzegania tych postanowień.

$\mathrm{Z}$ analogii należy podać przykład międzynarodowej procedury nakierowanej na osiągnięcie niezależności przez pacyficzne terytorium znajdujące się pod zwierzchnictwem Francji - Polinezję Francuską. Otóż od początku powstania Specjalnej Komisji ds. Dekolonizacji - organu ONZ odpowiedzialnego za monitorowanie postępów w drodze do osiągnięcia samodzielności prawnej, rząd w Paryżu nie zgadzał się z objęciem swoich wysp kompetencjami Komisji. Mikropaństwa na Pacyfiku Południowym ${ }^{18}$ otwarcie poparły dążenia narodowowyzwoleńcze sąsiada. Do tej pory trudno znaleźć podobny kazus dla regionalnego wsparciu Rapa Nui, które nie jest wszak zdecydowane co do wyboru formy funkcjonowania na arenie międzynarodowej. Bardziej bowiem niż o formalny zapis zarządzania Wyspą przedstawiciele autochtonicznej wspólnoty zabiegają o uznanie ich plemiennych praw, z prawem do ziemi i ochroną środowiska naturalnego włącznie.

Mimo że Chile jest stroną zarówno Deklaracji ONZ w sprawie praw ludów tubylczych (która nie jest umową wiążącą w rozumieniu międzynarodowego prawa traktatów), jak i Konwencji ILO o ludności autochtonicznej i plemiennej (brak chilijskiej ratyfikacji), ludność Rapa Nui nie może skutecznie powołać się na normy wynikające z tych porozumień. Co więcej, ani w Deklaracji, ani w Konwencji nie został przewidziany żaden system nadzorowania państw-metropolii czy też ewentualnych sankcji za nierespektowanie międzynarodowych praw mniejszości tubylczych, gdyż naruszałoby to prawnomiędzynarodową zasadę o zakazie ingerencji w sprawy wewnętrzne.

Odnosząc się do systemu regionalnego ochrony praw człowieka, należy przytoczyć trzy sprawy Międzyamerykańskiego Trybunału Praw Człowieka. Sam sąd został założony w 1979 r. w San José w Republice Kostaryki na podstawie założeń tzw. Paktu z San José - Amerykańskiej Konwencji Praw Człowieka z dnia 22 listopada 1969 r. Oprócz Trybunału amerykański system praw ochrony człowieka tworzy również Międzyamerykańska Komisja Praw Człowieka utworzona w 1959 r., z siedzibą w Waszyngtonie. Zarówno Komisja, jak i Trybunał powstały z inicjatywy organizacji regionalnej, jaką jest Organizacja Państw

17 Ustalenia Światowej Konferencji Praw Człowieka Organizacji Narodów Zjednoczonych, która odbyła się w dniach 14-25 czerwca 1993 r. w Wiedniu. Zostały one następnie spisane $\mathrm{w}$ formie deklaracji.

18 Mowa o Nauru, Samoa, Timor-Leste, Tuvalu, Vanuatu i Wyspach Salomona, które same przeszły przez proces dekolonizacji. 
Amerykańskich (Organization of American States - OAS), funkcjonująca od 1948 r. na podstawie Karty Organizacji Państw Amerykańskich z dnia 30 kwietnia 1948 r. podpisanej w Bogocie.

Pierwsze z orzeczeń, istotne dla możliwej poprawy sytuacji prawnej Rapa Nui, dotyczy mniejszości etnicznej zamieszkującej Nikaraguę. W 2001 r. przedstawiciele ludności Mayangna (zwani także Sumu) wnieśli pozew przeciwko rządowi w Managua w sprawie formalnego wyznaczenia wyłącznych terenów zgodnie z prawem ludności tubylczej do swobodnego dysponowania ziemią. Choć wyrok Trybunału jednoznacznie orzekł na rzecz powodów, rząd Nikaragui dopiero w 2008 r. dokonał demarkacji granic 73 ha obszaru. Po raz pierwszy w historii postkolonialnej Ameryki Łacińskiej padły podparte prawem międzynarodowym słowa: ,[...] autochtoniczne grupy, przez sam fakt ich egzystencji, mają prawo do swobodnego życia na własnym terytorium, podczas gdy ich bliskie więzi z ziemią muszą być uhonorowane i uznane za zasadnicze podstawy ich kultury, życia duchowego, integralności wraz z gospodarczym przetrwaniem" (Wyrok Mayagna (Sumo) Community of Awas Tingni v. Nicaragua, C/79).

Pięć lat później Trybunał wydał orzeczenie w sprawie prawa do użytkowania ziemi przodków w Paragwaju. Niezgodnie z Amerykańską Konwencją Praw Człowieka rząd w Asunción wywłaszczył z plemiennych terenów społeczność Sawhoyamaxa, pozbawiając ją elementarnego dostępu do wody pitnej, szkolnictwa i opieki zdrowotnej. Trybunał zasądził, że właśnie pozbawienie prawa do ziemi należy rozumieć szerzej, również jako zabronienie dostępu do leżącej na tym terenie wody oraz dostępu do infrastruktury. Strona oskarżona została zobowiązana do zwrotu nielegalnie zagrabionej ziemi, rekompensaty pieniężnej oraz zapewnienia dostępu do dóbr i usług fundamentalnych dla rozwoju wspólnoty (Wyrok Sawhoyamaxa Indigenous Community v. Paraguay, C/146).

Trzeci wyrok został wydany w 2012 r. w sprawie przeciwko Ekwadorowi. Postępowanie dotyczyło prawa do ochrony środowiska naturalnego oraz życia w zdrowym środowisku dla Kichwa - ludności amazońskiego regionu Sarayaku. Trybunał zasądził na rzecz aktywistów rekompensaty za pogwałcenie norm prawa międzynarodowego (Wyrok Kichwa People of Sarayaku v. Ecuador, C/245).

Powyższe przykłady jasno dowodzą, że regionalne normy ochrony praw człowieka (w tym ludności tubylczej) są dopiero na etapie tworzenia - zarówno zwyczaju międzynarodowego, jak i lokalnej jurysdykcji. Należy pamiętać, że Ameryka Łacińska to relatywnie młody region z postkolonialnym dorobkiem, który po latach dyktatur wojskowych ustanawia demokratyczny system sprawowania władzy. Prawa ludności plemiennej dopiero weszły do kanonu praw człowieka i są powoli inkorporowane do systemów narodowych. Dotyczy to także Chile i zależnego od niego Rapa Nui. 
W 2010 r. po krwawej pacyfikacji tłumu aktywistów oddolnie ustanowiono Komisję Rozwoju Wyspy Wielkanocnej (Comisión de Desarrollo de Isla de Pascua - CODEIPA). Organ ten, mający wszak wyłącznie kompetencje opiniotwórcze zamiast normotwórczych, podejmując różne działania, nagłaśnia łamanie praw ludności Rapa Nui (Young 2017). Z kolei Parlament Wyspy (Parlamento Rapa Nui), będący wbrew swojej nazwie organizacją społeczną, został nielegalnie utworzony w 2001 r. ${ }^{19}$ Jego główne założenia obejmują restytucję ziem zajętych w 1888 r., a także zmniejszenie migracji chilijskiej na teren Wyspy. Jak do tej pory największym sukcesem ruchu było nagłośnienie złej sytuacji prawnej Rapa Nui na forum ONZ oraz OAS. Działacze wykazali łamanie prawa wewnętrznego, tj. umowy zawartej w dniu 15 kwietnia 2015 r. pomiędzy władzami Chile a organizacjami ludności tubylczej. Punkty porozumienia odnosiły się do następujących problemów na linii Hanga Roa - Santiago: zarząd nad parkiem narodowym wraz z miejscami kultu religijnego i dziedzictwa przodków miał wrócić w ręce ludności tubylczej; Parlament Rapa Nui miał uszanować swobodny przepływ osób na terenie parku; w ciągu 60 dni od podpisania umowy administracja nad parkiem miała zostać ustanowiona zgodnie z założeniami Konwencji ILO. Uzgodnienia te jednak nie doczekały się realizacji (Young 2017).

W dniu 7 lutego 2011 r. Międzyamerykańska Komisja Praw Człowieka wystosowała zalecenia dla Chile z powództwa organizacji społecznych w Rapa $\mathrm{Nui}^{20}$. Petycja dotyczyła powtarzających się sytuacji (w 2010 r.) zastosowania niewspółmiernej siły porządkowej względem protestującej ludności Wyspy (Gallegos 2011). Jednakże orzeczenie (będące zaleceniem, a nie wiążącym postanowieniem) nie było respektowane przez chilijską stronę sporu. $\mathrm{Z}$ tego powodu w 2017 r. przedstawiciele Rapa Nui ponownie wnieśli powództwo do Komisji. Warto w tym miejscu dodać, że została wykorzystana procedura narodowa, a więc odwołanie do prezydenta Chile (w 2014 r. - Michelle Bachelet) w sprawie oddania terenów pod zarząd ludności tubylczej. Okazało się to jednak bezskuteczne, dlatego wnioskodawcy odnieśli się do systemu regionalnego ochrony praw człowieka. Ponownie wniesiono pozew do Komisji w dniu 27 marca 2014 r., tym razem głównym zarzutem było nierespektowanie przez

19 Organizacja powstała w dniu 5 sierpnia $2001 \mathrm{r}$. Nie posiada strony internetowej, a jedynie grupę na Facebooku: https://www.facebook.com/pg/parlamentorapanui/about/?ref=page_internal. Dokument z 2013 r. (Documento del Parlamento Rapanui), niebędący wszak aktem założycielskim, lecz luźnym spisem postulatów, dostępny jest na stronie Le Monde diplomatique (https://www. lemondediplomatique.cl/Documento-del-Parlamento-Rapanui.html).

20 Znaczącą rolę powoda odegrała tutaj naukowa organizacja Indian Law Resource Center. Por. wpisy na blogu: https://indianlaw.org/content/disputes-over-rapa-nui-sacred-sites-leads-moreviolent-evictions; https://indianlaw.org/rapa-nui/home. 
Chile prawa autochtonów do swobodnych zgromadzeń oraz dysponowania zasobami środowiska, w tym ziemi ${ }^{21}$. Jak dotąd nie zapadł wyrok w tej sprawie.

\section{WNIOSKI}

Należy podkreślić, że społeczność Rapa Nui posiada kilka prawnomiędzynarodowych możliwości sformalizowania swojej pozycji na arenie międzynarodowej, co daje szansę na polepszenie sytuacji prawnej oraz wzrost dobrobytu ludności. Mowa tutaj o systemie wypracowanym przez ONZ, którego Chile jest częścią, a także o innych metodach ochrony dziedzictwa kulturowego i tożsamości. Prawna sytuacja Rapa Nui nie jest uregulowana w porządku chilijskim, co jednak nie oznacza przyzwolenia na łamanie jej uprawnień przez rząd w Santiago. W świetle regionalnych norm prawa międzynarodowego należy zauważyć, że istnieją wypracowane mechanizmy ochrony ludności tubylczej, z czego skorzystali już przedstawiciele plemion państw Ameryki Łacińskiej oraz Rapa Nui. Mimo że są to dopiero początki drogi sądowej, istnieją jasno określone postępowania, dzięki którym możliwe będzie zadośćuczynienie historycznych krzywd oraz zapewnienie ochrony w przyszłości.

Porządek ONZ i OAS daje gwarancje ochrony niezbywalnych praw mniejszościom etnicznym, w tym autochtonicznym, co stanowi otwartą drogę dla Rapa Nui do: występowania w obronie prawa do ziemi, życia w niezanieczyszczonym środowisku naturalnym, poszanowania miejsc kultu religijnego i archeologicznych miejsc składających się na dziedzictwo kulturowe, a wreszcie samodecydowania o migracji na swoje terytorium i reagowania na zmiany etniczne własnej wyspy. Pytanie o model formy prawno-ustrojowej Rapa Nui jako państwa nadal pozostaje otwarte. Choć pozostałe pacyficzne mikropaństwa wybrały niepodległą bądź wolno stowarzyszoną formę funkcjonowania na arenie regionalnej, to Rapa Nui nie jest do końca do tego przekonane. Aktywiści jasno wskazują na rozwojowo-cywilizacyjne uzależnienie od dostaw surowców, jedzenia i opieki zdrowotnej, edukacji czy infrastruktury bezpośrednio z Chile. Odcinając się od Santiago, Rapa Nui straciłoby te istotne do przetrwania swych mieszkańców transfery (Romero 2012).

21 Por. wpisy na blogu Human Rights Brief prowadzonym przez Centrum Praw Człowieka przy American University Washington College of Law: http://hrbrief.org/hearings/human-rights-situation-rapa-nui-people-chile; http://hrbrief.org/hearings/indigenous-peoples-right-to-priorconsultation-in-chile. 


\section{BIBLIOGRAFIA}

\section{LITERATURA}

Campbell P., 2006: Easter Island: On the Verge of a Second Environmental Catastrophe. Rapa Nui Journal, 20(1), 67-70.

Castri F. di, 2003: The Dynamic Future of Rapa Nui. Rapa Nui Journal, 17(1), 44-48.

Coulter R.T., 2015: The Situation of the Indegenious People of Rapa Nui and International Law: Reflections on Indigenious People and the Ethics of Remediation. Santa Clara Journal of International Law, 13(1), 293-305.

Gacitúa-Marió E., 2000: Indigenous Peoples in Chile: Current Situation and Policy Issues. Poverty and Income Distribution in a High Growth Economy: The Case of Chile 1987-98, 2/7, 170-196.

Gallegos I., 2011: Easter Island Rapa Nui peoples' land claims'turns international. Merco Press, 10.02.2011.

Hannum H., 1993: Rethinking Self-Determination. Virginia Journal of International Law, 34(1), 1-69.

Hito S., 2004: Vaai Hanga Kainga Giving Care to the Motherland: Conflicting Narratives of Rapanui. Journal of Intercultural Studies, 25(1), 22-34. https://doi.org/10.1080/072568604100 01686992

Jędrusik M., 2005: Wyspy tropikalne. W poszukiwaniu dobrobytu. Wyd. Uniwersytetu Warszawskiego, Warszawa.

Legrand C., 2013: Easter Island issues Chile with independence threat. The Guardian, 15.01.2013.

Levine S., 2016: Pacific Ways: Government and Politics in the Pacific Islands. Victoria University Press, Wellington.

Pawlicki J., 2014: Cały smutek Rapa Nui, czyli dramat Wyspy Wielkanocnej. Newsweek, 20.04.2014.

Pereyra-Uhrle M., 2011: Easter Island Land Law. New Zealand Association of Comparative Law, $12,133-142$.

Romero S., 2012: Slow-Burning Challenge to Chile on Easter Island. The New York Times, 6.10.2012.

Young F.W., 2016: Rapa Nui. The Contemporary Pacific, 28(1), 237-244. https://doi.org/10.1353/ cp. 2016.0022

Young F.W., 2017: Rapa Nui. The Contemporary Pacific, 29(1), 173-181. https://doi.org/10.1353/ cp.2017.0013

\section{AKTY PRAWNE}

Amerykańska Konwencja Praw Człowieka z dnia 22 listopada 1969 r.

Deklaracja praw ludów tubylczych z dnia 13 września $2007 \mathrm{r}$.

Deklaracja Zgromadzenia Ogólnego ONZ z dnia 14 grudnia 1960 r. w sprawie przyznania niepodległości krajom kolonialnym GA Res. 1514 (XV).

Deklaracja Zgromadzenia Ogólnego ONZ z dnia 24 października 1970 r. w sprawie zasad prawa międzynarodowego dotyczących przyjaznych stosunków i współpracy między państwami GA Res. 2625 (XXV). 
Karta Narodów Zjednoczonych z dnia 26 czerwca 1945 r. (Dz.U. 1947, nr 23, poz. 90).

Karta Organizacji Państw Amerykańskich z dnia 30 kwietnia 1948 r.

Konstytucja Polityczna Republiki Chile (Constitución Política de la República de Chile de 1980) z dnia 8 sierpnia 1980 r. (Ministerio Secretaría General De La Presidencia CPR Art. $1^{\circ}$ D.O. 24.10.1980 LEY N 19.611 Art. Único Nº1 D.O. 16.06.1999).

Konwencja MOP nr 169 w sprawie ludności rdzennej i plemiennej z dnia 27 czerwca 1989 r.

Międzynarodowy Pakt Praw Gospodarczych, Społecznych i Kulturalnych z dnia 16 grudnia 1966 r. (Dz.U. 1977, nr 38, poz. 169).

Międzynarodowy Pakt Praw Obywatelskich i Politycznych z dnia 16 grudnia 1966 r. (Dz.U. 1977, nr 38, poz. 167).

Powszechna Deklaracja Praw Człowieka z dnia 10 grudnia 1948 r.

Prawo rozwoju lokalnego (Ley de Desarrollo Indígena) z dnia 5 października 1993 r. (LEY 20117 Art. Único D.O. 08.09.2006).

Principles which should guide Members in determining whether or not an obligation exists to transmit the information called for under Article 73e of the Charter, 15 December 1960 GA Res. 1541 (XV).

Reforma konstytucyjna ustanawiająca specjalne terytoria Wyspy Wielkanocnej i archipelagu Juana Fernandeza (Reforma Constitucional Que Establece Los Territorios Especiales De Isla De Pascua Y Archipielago Juan Fernandez) z dnia 30 lipca 2007 r.

\section{ORZECZNICTWO}

Wyrok Kichwa People of Sarayaku v. Ecuador, C/245 (27.06.2012).

Wyrok Mayagna (Sumo) Community of Awas Tingni v. Nicaragua, C/79 (31.08.2001).

Wyrok Sawhoyamaxa Indigenous Community v. Paraguay, C/146 (29.05.2006).

\section{ŹRÓDŁA INTERNETOWE}

http:/hrbrief.org/hearings/human-rights-situation-rapa-nui-people-chile

http://hrbrief.org/hearings/indigenous-peoples-right-to-prior-consultation-in-chile

https://indianlaw.org/content/disputes-over-rapa-nui-sacred-sites-leads-more-violent-evictions

https://indianlaw.org/rapa-nui/home

https://minorityrights.org/minorities/rapanui

https://nvdatabase.swarthmore.edu/content/rapa-nui-campaign-immigration-regulation-2009

https://whc.unesco.org/en/list/715

https://www.berkeley.edu/news/media/releases/2002/11/peace/rapu.html

https://www.cia.gov/library/publications/resources/the-world-factbook/geos/print_ci.html

http://www.coha.org/limiting-migration-to-rapa-nui

http:// www.facebook.com/pg/parlamentorapanui/about/?ref=page_internal

https://www.france24.com/en/20180730-easter-island-rapa-nui-chile-restrict-length-stay-nontourists

https://www.lemondediplomatique.cl/Documento-del-Parlamento-Rapanui.html 